José Florencio F. Lapeña, Jr., M.A., M.D.

Department of Otorhinolaryngology

College of Medicine, University of the Philippines Manila

Department of Otorhinolaryngology

Head and Neck Surgery

East Avenue Medical Center, Diliman, Quezon City
Correspondence: Prof Dr. José Florencio F. Lapeña, Jr.

Department of Otorhinolaryngology

Ward 10, Philippine General Hospital

University of the Philippines Manila

Taft Ave., Ermita, Manila 1000

Philippines

Phone (632) 5264360

Telefax (632) 5244455

Email lapenajf@upm.edu.ph

Reprints will not be available from the author.

The author declared that this represents original material that is not being considered for publication or has not been published or accepted for publication elsewhere, in full or in part, in print or electronic media; that the manuscript has been read and approved by the author, that the requirements for authorship have been met by the author, and that the author believes that the manuscript represents honest work.

Disclosures: The author has no relevant financial or other (including personal) relationships, intellectual passion, political or religious beliefs, and institutional affiliations that might lead to a conflict of interest.

\section{From Alma Ata to Dakar: Health for All, Education for All}

Like the Alma Ata declaration' of "health for all by the year 2000," the Dakar framework for action ${ }^{2}$ and "education for all by 2015" will not be achieved as envisioned. Of the many determinants and barriers to universal access to health and education, the intersection of health with education itself represents a major barrier. The social determinants of health ${ }^{3}$ can themselves pose barriers to education. Maternal and infant mortality and morbidity, homelessness, hunger and malnutrition, poor sanitation, lack of security and life-sustaining resources impact on both health and education, and "damaged brains and bodies" cannot learn optimally.

Health education aims to address these barriers in a special manner and on several levels, beginning with pre-school formal and non-formal community-based health education of children, their parents and community health workers, through formal kindergarten to grade 12 education of schoolchildren (the Philippine Government K-12 implementation) as well as nonformal education of out-of-school youth (Cf: the "Kareton Klassroom" concept of 2011 CNN Hero of the Year Efren Peñaflorida). Tertiary undergraduate, graduate and postgraduate education in health professions and allied medical professions is the unique mission of the University of the Philippines Manila, as the National Health Sciences Center. Together with other public and private institutions, government and non-government organizations and the private sector (including the Philippine Society of Otolaryngology Head and Neck Surgery, the Philippine College of Surgeons, and the Philippine Medical Association), tertiary health education should aim to make an impact on all other levels of health education in particular, and education in general. This effect should happen during the process of education, and not just after - a synchronous multilevel model that is well-entrenched in the medical and health care professions. Consultants teach residents and medical students, residents teach medical students and health workers, medical students teach health workers, and so on, as all teach patients and their care-givers also.

Inequitable access to health is a major barrier to educational access (and vice versa), and solutions to lower or eliminate this barrier will hinge on acquiring adequate and accurate information on universal health coverage, people-centered/point-of-care services, public policy, leadership and governance. ${ }^{4}$ Moreover, information on psychosocial, socio-cultural, economic, ecological-environmental and political contexts and realities, especially in such a geolinguistically diverse country as the Philippines is of utmost importance to any leader in health, in education and in health education. The quality of information, as reflective of reality rather 
than merely representative of rhetoric, is just as important (but even more difficult to acquire). Otherwise, any solutions conceived of and developed will fall far short of their targets or entirely miss the mark. The interpretation of such information should likewise remain faithful to the original contexts. Therefore, the acquisition and utilization of such information should involve a cooperative, participatory, inter-disciplinary and multi-level effort among various stakeholders, including the people (beneficiaries) themselves. Our research efforts should take these into consideration, as should the dissemination of these efforts, primarily (in our case) through the Philippine Journal of
Otolaryngology Head and Neck Surgery.

Many of us perform multiple educational roles in academic and training institutions, and in our respective subspecialty interest and study groups. Our teaching and training programs, as well as our advocacies, should benefit health, education, and health education in the Philippines, and the people that we ultimately serve. Let us learn from the past, so that we can move into the future. As educational leaders, it is of paramount importance to be well informed of what has transpired, so that being inspired, leaders and stakeholders together can positively transform their situations in life and their realities.

1. WHO \& UNICEF (1978). Declaration of Alma-Ata. Geneva, World Health Organization. Available from http://www.who.int/hpr/NPH/docs/declaration_almaata.pdf Accessed March 17, 2012.

2. UNESCO (2000). The Dakar framework for action. Education for all: meeting our collective commitments. Paris, United Nations Educational, Scientific and Cultural Organization. Available from http://unesdoc.unesco.org/images/0012/001211/121147e.pdf Accessed March 15, 2012.

3. CSDH (2008). Closing the gap in a generation: health equity through action on the social determinants of health. Final Report of the Commission on Social Determinants of Health. Geneva, World Health Organization. Available from http://www.who.int/social_determinants/ thecommission/finalreport/en/index.html Accessed March 17, 2012.

4. WHO (2008). The world health report 2008- primary health care (now more than ever). Geneva, World Health Organization. Available from http://www.who.int/whr/2008/en/index.htm Accessed February 17, 2012. 